\title{
DAMPAK SILATURAHIM PADA KINERJA USAHA ANGGOTA HIPMI SURABAYA
}

\author{
Gandhi Satrya Kumajaya \\ Mahasiswa Program Studi S-1 Ekonomi Islam - Fakultas Ekonomi dan Bisnis - Universitas \\ Airlangga \\ Muhammad Nafik H.R. \\ Departemen Ekonomi Syariah - Fakultas Ekonomi dan Bisnis - Universitas Airlangga \\ Email: manhard999@yahoo.com
}

\begin{abstract}
Research aims to know impact silaturahim performance business members HIPMI Surabaya. This research use qualitative approach and kind of his research use eksplanatori. This research use the kind of research eksplanatori for want of analyzing relation between one variable other variables or how can a variables affecting other variables. Strategy used in this research is case study.

The result showed that silaturahim between members HIPMI Surabaya able to create social interaction or interpersonal communication. The more interpersonal communication process for entrepreneurs, then synergy between employers who one by another be interwoven. Synergy the can bring business cooperation and increase knowledge about business itself. Those things that influences the performance business members HIPMI Surabaya. Increasing the efforts can be seen through increased turnover, profit, value, of market share, and labor owned entrepreneurs who belongs to a HIPMI Surabaya.
\end{abstract}

Keywords: gathering, interpersonal communication, synergy, the performance of business

\section{PENDAHULUAN}

\section{A. Latar Belakang}

Di Indonesia masalah pengangguran dan kemiskinan bukan hanya persoalan ekonomi semata, melainkan juga persoalan sosial, budaya, dan politik. Masalah pengangguran dan kemiskinan masih merupakan masalah besar yang dihadapi bangsa Indonesia sekarang dan beberapa tahun ke depan. Menurut (Sinar Tani, Maret 2009) dalam (Suryana dan Katib, 2011 : 10), pada tahun 2008 tercatat jumlah penduduk miskin di Indonesia mencapai 34.96 juta jiwa atau 15,42\% dari seluruh penduduk Indonesia. Jumlah penganggur turun dari 10,55 juta orang atau $9,7 \%$ tahun 2006 menjadi 9,43 juta orang atau 8,5\% tahun 2007 dan menjadi 9,26 juta orang atau $8,1 \%$ pada

tahun 2009.

Menurut (Suryana dan Katib, 2011:31) menyatakan bahwa, Indonesia masih memerlukan ratusan ribu atau bahkan berjuta-juta pengusaha dan perusahaan kecil. Sejarah telah membuktikan bahwa di negara modern pun eksistensi atau kehidupan perusahaan kecil tetap terjamin. Keyakinan ini, semakin berdasar melihat tekad pemerintah Indonesia, pembinaan perusahaan kecil seperti dirumuskan dalam pasal 14 UU No. 9/1995 tentang usaha kecil, dan masyarakat melakukan pembinaan dan pengembangan usaha kecil dalam bidang: (1) Produksi dan pengelolaan, (2) Pemasaran, (3) Sumber 
daya manusia, dan (3) Teknologi. Menurut (Alma, 2011:5) bahwa, keberhasilan pembangunan yang dicapai oleh negara Jepang ternyata disponsori oleh wirausahawan yang telah berjumlah $2 \%$ tingkat sedang, berwirausaha kecil sebanyak $20 \%$ dari jumlah penduduknya. Inilah kunci keberhasilan pembangunan negara Jepang.

Masyarakat Indonesia yang sebagian besar beragama Islam tidak mengetahui akan ajaran Islam tentang pekerjaan di bidang bisnis. Islam menjelaskan dalam kitab suci Al-Qur'an semua hal dalam kehidupan sebagai petunjuk bagi umat muslim. Salah satunya adalah penjelasan bahwa perdagangan atau bisnis adalah suatu profesi yang terhormat di dalam ajaran Islam. Hal ini dapat dilihat dari isi Al-Qur'an dan hadist Rasulullah SAW yang banyak menyebutkan dan menjelaskan normanorma perdagangan dan jual beli business. Nabi Muhammad SAW adalah seorang businessman yang sangat terkenal kemampuanya dalam berdagang. Reputasi Rasulullah SAW dalam dunia bisnis demikian bagus sehingga dikenal luas di Yaman, Syiria, Yordania, Irak, Basrah, dan kota-kota perdagangan lain di Jazirah Arab.

Rasulullah SAW bersabda:

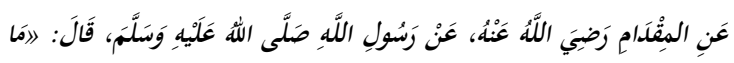

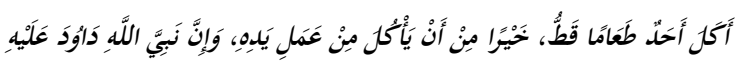

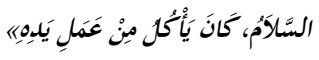

"Dari Miqdam berkata, Rasululloh SAW bersabda: Tidak makan seseorang akan makanan yang lebih baik, dari makan usaha tangannya sendiri dan sesungguhnya Nabi Allah Daud AS. makan dari usaha tangannya sendiri". (H.R. Bukhari)

Islam sebagai agama yang sempurna memberikan petunjuk kepada manusia tentang bidang usaha yang halal, cara berusaha, dan bagaimana manusia harus mengatur hubungan kerja sama agar memberikan manfaat yang baik serta dapat menciptakan kesejahteraan dan kemakmuran bagi manusia. Islam tidak hanya mengajarkan manusia bekerja bagi kepentingan dirinya sendiri secara halal, akan tetapi juga memerintahkan manusia menjalin hubungan kerja sama dengan orang lain bagi kepentingan dan keuntungan kehidupan manusia. Islam memandang bahwa berwirausaha merupakan bagian dari ajaran agama, hal ini dapat dilihat dari sejumlah firman-firman Allah SWT dan hadist Rasulullah SAW yang menjelaskan pentingnya aktifitas berwirausaha seperti yang terkandung di dalam surat Al Jumuah ayat 11:

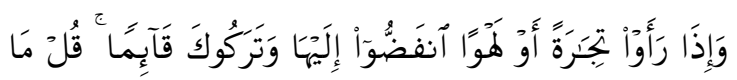

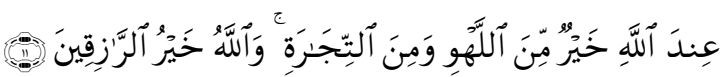

Wa idzaa ra-au tijaaratan au lahwaanin fadhdhuv ilaihaa wa tarakuuka qaaiman qul maa 'indallaahi khairum minal lahwi wa minat tijaarati wallaahu khairur raaziqiin.

"Dan apabila mereka melihat perniagaan atau permainan, mereka bubar untuk 
menuju kepadanya dan mereka tinggalkan kamu sedang berdiri (berkhotbah). Katakanlah: "apa yang disisi Allah lebih baik daripada permainan dan perniagaan", dan Allah sebaik-baik pemberi rezeki"

\section{LANDASAN TEORI \\ PENGEMBANGAN PROPOSISI}

DAN

\section{A. Silaturahim}

Silaturahim adalah salah satu sunnah yang dianjurkan oleh Rasulullah SAW, karena di dalam silaturahim banyak terkandung akan manfaat dan keutamaan silaturahin itu sendiri. Manusia adalah mahkluk sosial yang memerlukan hubungan dengan manusia lainnya dalam kehidupan sehari-hari. Makna silaturahim tidak sebatas bersalaman atau kunjungan antar keluarga dan pertemuan warga atau kerabat. Silaturahim memiliki makna yang lebih luas, yaitu bagaimana upaya manusia dalam memelihara dirinya sendiri dan keluaraga agar tetap istiqomah atau konsisten dalam keimanan seperti yang diisyaratkan oleh firman Allah SWT. Silaturahim merupakan akhlak seorang muslim sebagaimana yang terkandung dalam firman Allah SWT surat An Nissa ayat 1:

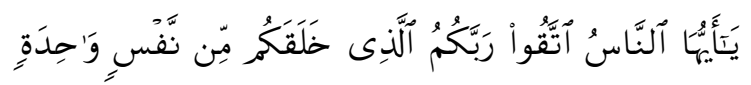

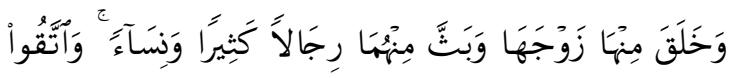

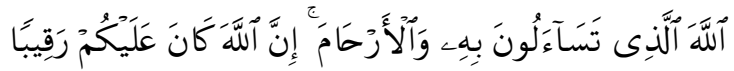

ya ayyuha alnnasu ittaqoo rabbakumu alladzii khalaqakum min nafsin wahidatin wakhalaqa minha zawjaha wabaththa minhuma rijalan katheeran wanisaan waittaqoo Allaha alladzii tasaaloona bihi waalarhama inna Allaha kana AAalaykum raqeeban

"Hai sekalian manusia, bertakwalah kepada Tuhan-mu yang telah menciptakan kamu dari seorang diri, dan dari padanya Allah menciptakan istrinya; dan dari pada keduanya Allah memperkembang biakkan laki-laki dan perempuan yang banyak. Dan bertakwalah kepada Allah yang dengan (mempergunakan) nama-Nya kamu saling meminta satu sama lain, dan (peliharalah) hubungan silaturahim. Sesungguhnya Allah selalu menjaga dan mengawasi kamu."(QS. An-nisa:1)

\section{B. Manfaat Silaturahim}

Keutamaan silaturahim diantara adalah dipanjangkan umur dan dilapangkan rezekinya, sebagaimana yang terkandung di dalam hadist Rasulullah SAW :

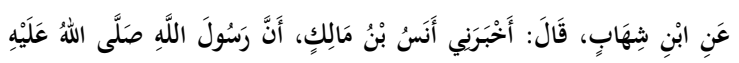

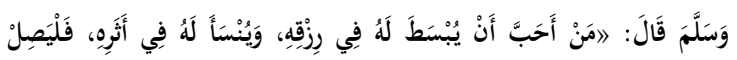
زَحِمَأُ

"Siapa yang ingin rezekinya dipanjangkan, maka hendaklah ia menyambung silaturrahmi"'(HR. Muslim, dari Anas bin Malik).

C. Berwirausaha Sebagai Salah Satu Sumber Pencapaian Rezeki yang Halal Menurut Basrowi (2011: 1) menjelaskan, Kewirausahawan berasal 
dari kata wira dan usaha. Wira berarti pejuang, pahlawan, manusia unggul, teladan, berbudi luhur, gagah berani, dan berwatak agung. Usaha berarti perbuatan amal, bekerja, atau berbuat sesuatu. Kesimpulanya adalah, wirausaha adalah pejuang atau pahlawan yang berbuat sesuatu.

Islam menjelaskan dalam kitab suci Al-Qur'an semua hal dalam kehidupan sebagai petunjuk bagi umat muslim. Salah satunya adalah penjelasan bahwa perdagangan atau bisnis adalah suatu profesi yang terhormat di dalam ajaran Islam. Hal ini dapat dilihat dari isi Al-Qur'an dan hadist Rasulullah SAW yang banyak menyebutkan dan menjelaskan normanorma perdagangan dan jual beli business. Nabi Muhammad SAW adalah seorang businessman yang sangat terkenal kemampuanya dalam berdagang. Reputasi Rasulullah SAW dalam dunia bisnis demikian bagus sehingga dikenal luas di Yaman, Syiria, Yordania, Irak, Basrah, dan kota-kota perdagangan lain di Jazirah Arab. Rasulullah SAW bersabda:

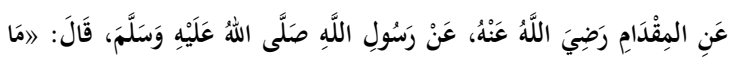

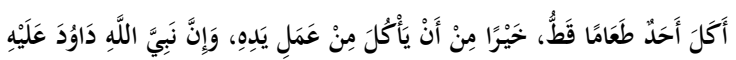

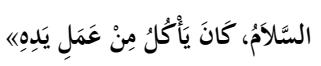

"Dari Miqdam berkata, Rasululloh SAW bersabda: Tidak makan seseorang akan makanan yang lebih baik, dari makan usaha tangannya sendiri dan sesungguhnya Nabi Allah Daud AS. makan dari usaha tangannya sendiri". (H.R. Bukhari)

\section{Pengertian Komunikasi Interpersonal}

Komunikasi interpersonal memiliki definisi yang banyak sebagaimana para ahli-ahli komunikasi memberikan pengertian sesuai dengan batasanbatasan yang ada. (Trenholm, dkk, 1995:26) dikutip oleh Suranto (Suranto, 2011:3) di dalam bukunya yang berjudul "Komunikasi Interpersonal" mendefinisikan komunikasi interpersonal sebagai komunikasi antar dua orang yang berlangsung secara tatap muka. Sifat komunikasi ini adalah: (a) spontan dan informal; (b) saling menerima feedback secara maksimal; (c) partisipan berperan fleksibel.

M. Hardjana (2003:85) yang dikutip oleh (Suranto, 2011:3) mengatakan, komunikasi interpersonal adalah interaksi tatap muka antar dua atau beberapa orang, di mana pengirim dapat menyampaikan pesan secara langsung dan penerima pesan dapat menerima dan menanggapi secara langsung. Pendapat senada juga diungkapkan oleh (Mulyana, 2008:81) yang dikutip oleh (Suranto, 2011:3), bahwa komunikasi interpersonal atau komunikasi antar pribadi adalah komunikasi antara orangorang secara tatap muka, yang memungkinkan setiap pesertanya menangkap reaksi orang lain secara langsung, secara verbal maupun nonverbal.

(Suranto, 2011:5) menyimpulkan bahwa komunikasi interpersonal atau komunikasi antar pribadi adalah proses 
penyampaian dan penerimaan pesan antara pengirim pesan (sender) dengan penerima (receiver) baik secara langsung (primer) apabila pihak-pihak yang terlibat komunikasi dapat saling berbagai informasi tanpa melalui media. Sedangkan komunikasi tidak langsung (sekunder) dicirikan oleh adanya penggunaan media tertentu.

\section{E. Pengertian Kinerja}

Masalah yang sering dihadapi di dalam kinerja adalah pada aspek etika kerja seperti ketidak kejujuran, ketidak disiplinan, ketidak adilan, kecurangan pertanggung jawaban administrasi, dan sebagainya. Tb. Syafri (2009: 216) berpendapat etika kerja adalah aturan normatif yang mengandung sistem nilai dan prinsip moral yang merupakan pedoman bagi karyawan dalam melaksanakan tugas pekerjaanya dalam perusahaan.

Kinerja berasal dari pengertian Performance. Ada pula yang memberikan pengertian Performance sebagai hasil kerja atau prestasi kerja. Namun, sebenarnya kinerja mempunyai makna yang lebih luas, bukan hanya hasil kerja, tetapi termasuk bagaimana proses pekerjaan berlangsung (Wibowo, 2008:7). Armstrong dan Baron (1998:15) yang dikutip oleh Wibowo (2008:7) di dalam bukunya yang berjudul "Manajemen Kinerja" mengungkapkan bahwa kinerja merupakan hasil pekerjaan yang mempunyai hubungan kuat dengan tujuan strategis organisasi, kepuasan konsumen, dan memberikan kontribusi pada ekonomi.

\section{F. Kineja Usaha atau Perusahaan}

Menurut (Chakravarthy dan Balaji, 1986) dalam (Agus Handoyo, 2001:32) menyatakan, bahwa kinerja perusahaan adalah variabel dependen yang digunakan untuk mengukur keberhasilan perusahaan didalam pencapaian tujuannya. Kinerja merupakan konsep yang umum digunakan untuk mengukur dampak orientasi dan strategi yang diterapkan perusahaan. Menurut (Jauch dan Glueck, 1988) dalam (Suci, 2009:48) menyatakan, bahwa kinerja adalah merujuk pada tingkat pencapaian atau prestasi dari perusahaan dalam periode waktu tertentu. Kinerja sebuah perusahaan adalah hal yang sangat menentukan dalam perkembangan perusahaan. Tujuan perusahaan yang terdiri dari: tetap berdiri atau (survive), untuk memperoleh laba (benefit) dan dapat berkembang (growth), dapat tercapai apabila perusahaan tersebut mempunyai performa yang baik. Kinerja (performa) perusahaan dapat dilihat dari tingkat penjualan, tingkat keuntungan, pengembalian modal, tingkat turn over dan pangsa pasar yang diraihnya. (Miner, 1992) dalam (Darya, 2012:68) menyatakan, bahwa kinerja usaha merupakan suatu yang lazim digunakan untuk memantau produktifitas kerja sumber daya manusia baik yang berorientasi produksi barang, jasa maupun pelayanan. Kinerja menurut Islam 
dijelaskan dalam firman Allah SWT surat An-Najm ayat 39-41, yang berbunyi :

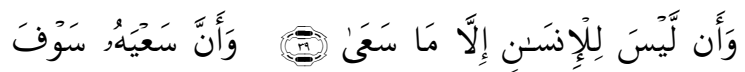

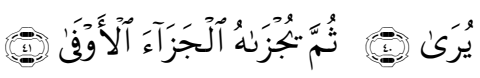

Wa-an laysa lil-insaani illaa maa sa'aa. Wa-anna sa'yahu sawfa yuraa. Tsumma yujzaahu aljazaa-a al-awfaa

"Dan bahwasanya seorang manusia tiada memperoleh selain apa yang telah diusahakannya. Dan bahwasanya usaha itu kelak akan diperlihatkan (kepadanya). Kemudian akan diberi balasan kepadanya dengan balasan yang paling sempurna"

\section{G. Pengukuran Kinerja}

Prawirosentono

(1999;

berpendapat sebagai berikut : "Kinerja setiap unit kerja harus diukur dengan metode statistik, khususnya tentang mutu suatu produksi. Manajer harus menerima tanggung jawab atas kinerja bawahanya, jika bawahanya berkinerja buruk manajer jangan sekedar menyalahkan bawahanya saja. Manajer harus selalu memonitor setiap bawahanya berdasarkan kendali statistik."

\section{Berdasarkan pengukuran kinerja}

oleh beberapa ahli, penelitian ini menggunakan Metode Balanced Scorecard sebagai dasar dan acuan pengukuran kinerja usaha anggota HIPMI Surabaya. Metode Balanced Scorecard merupakan metode pengukuran kinerja yang terintegrasi dan mencakup keseluruhan aspek finansial dan non finansial. metode balanced scorecard merupakan metode yang menerjemahkan visi, misi dan strategi perusahaan ke dalam seperangkat sasaran-sasaran strategis, yang dirumuskan menggunakan empat prespektif yang satu dengan yang lainya saling berhubungan dan tidak dapat dipisahkan. Menurut (Kaplan dan Norton, 1996:25-29) menjelaskan tentang keempat prespektif tersebut sebagai berikut:

1. Prespektif keuangan.

Prespektif keuangan menunjukkan apakah strategi bersaing yang dipilih memberikan kontribusi terhadap perbaikan kinerja keuangan baik jangka pendek maupun jangka panjang. Terdapat tiga aspek strategis berkaitan dengan aspek keuangan yaitu: (1) pertumbuhan pendapatan (revenue growth), (2) pengurangan biaya (cost reduction), (3) pemanfaatan aktiva (asset untilation).

2. Prespektif pelanggan.

Menunjukkan keberhasilan perusahaan dalam menarik dan mempertahankan pelanggan, yang selanjutnya akan menentukan keberhasilan dalam meraih pangsa pasar yang dituju.

3. Prespektif proses bisnis internal.

Dalam prespektif ini perusahaan harus melaqkukan perbaikan terhadap semua aktivitas internal dalam menciptakan produk yang dapat memberikan kepuasan tertentu bagi pelanggannya. Untuk tujuan tersebut perusahaan harus fokus pada tiga aspek yaitu: (1) inovasi, (2) operasi, dan (3) layanan purna jual. 
4. Prespektif pembelajaran dan pertumbuhan.

Fungsinya yaitu mengukur kemampuan perusahaan untuk mengembangkan dan memanfaatkan sumber daya manusia sehingga tujuan strategik perusahaan dapat tercapai untuk masa sekarang dan masa yang akan datang

Berdasarkan sistem pengukuran kinerja BSC dengan menggunakan empat prespektif, maka penelitian ini menggunakan pengukuran secara subjektif dengan indikator omset, laba, value, pangsa pasar, dan tenaga kerja. Alasan penelitian ini menggunakan pengukuran kinerja secara subjektif daripada secara objektif adalah yang pertama, informasi data secara subjektif akan mudah didapat daripada informasi data secara objektif. Data keuangan objektif pada perusahaan-perusahaan atau data dari bentuk suatu usaha dalam penelitian ini tidak dipublikasikan secara akurat dan kadang tidak tersedia, hal ini lah yang menjadi pertimbangan untuk tidak menggunakan metode pendekatan secara objektif. Kedua, pengukuran secara subjektif melalui indikator omset, laba, value, pangsa pasar, dan tenaga kerja akan lebih tepat digunakan dalam sebuah penelitian dimana objek penelitian terdiri dari bentuk usaha yang berbeda-beda.

Penelitian ini menggunakan subjek seorang wirausaha yang masuk dalam anggota HIPMI Surabaya. Melalui pengukuran kinerja dengan menggunakan indikator omset, laba, value, pangsa pasar, dan tenaga kerja peneliti ingin mengetahui tentang kinerja dari seorang wirausaha. Melalui omset dari usaha yang dijalankan, kemudian laba yang dihasilkan, value yang didapat dari seorang wirausaha anggota HIPMI Surabaya itu sendiri, pangsa pasar dari usaha, dan tenaga kerja yang dapat dikelola oleh pengusaha anggota HIPMI Surabaya.

Indikator peningkatan kinerja dalam penelitian ini adalah hasil usaha atau hasil kerja seseorang yang dicapai dengan adanya kemampuan dan perbuatan dalam situasi tertentu, bekerja dengan cara yang benar dan baik, hasil kerja dapat memberikan manfaat dalam hidup, kesejahteraan finansial yang layak dan mencukupi, prestasi yang dicapai oleh seseorang sebagai perwujudtan hasil kerja yang keras dan selalu ingin maju. Hasil wawancara dengan masing-masing informan adalah sebagai berikut :

\section{DESKRIPSI HASIL DAN PEMBAHASAN}

\section{A. Pembahasan}

Hasil wawancara dengan beberapa pengusaha yang tergabung di dalam HIPMI Surabaya dapat dilihat melalui tabel wawancara dibawah ini

\section{B. Hasil Wawancara dengan Pengusaha}

\section{Anggota HIPMI Surabaya}

Tabel 1.

Hasil Wawancara dengan Pengusaha

Anggota HIPMI Surabaya

\begin{tabular}{|l|l|l|}
\hline $\begin{array}{l}\text { Informan } \\
\text { atau }\end{array}$ & $\begin{array}{l}\text { Manfaat } \\
\text { Pergaulan }\end{array}$ & $\begin{array}{l}\text { Dampak } \\
\text { Terhadap }\end{array}$ \\
\hline
\end{tabular}




\begin{tabular}{|c|c|c|}
\hline $\begin{array}{l}\text { Pengusaha } \\
\text { anggota } \\
\text { HIPMI } \\
\text { Surabaya }\end{array}$ & & $\begin{array}{l}\text { Kinerja } \\
\text { Usaha } \\
\text { Anggota } \\
\text { HIPMI } \\
\text { Surabaya }\end{array}$ \\
\hline $\begin{array}{l}1 . \\
\text { Pengusaha } \\
\text { barang- } \\
\text { barang } \\
\text { antik }\end{array}$ & $\begin{array}{l}\text { Menambah } \\
\text { networking, } \\
\text { informasi } \\
\text { baru, dan } \\
\text { pangsa } \\
\text { pasar }\end{array}$ & $\begin{array}{l}\text { Memperbai } \\
\mathrm{ki} \\
\text { manajemen } \\
\text { pemasaran } \\
\text { dengan } \\
\text { cara baru, } \\
\text { dan } \\
\text { menciptaka } \\
\mathrm{n} \text { peluang } \\
\text { bisnis yang } \\
\text { baru }\end{array}$ \\
\hline $\begin{array}{l}2 . \\
\text { Pengusaha } \\
\text { photograph } \\
\text { er wedding }\end{array}$ & $\begin{array}{l}\text { Menambah } \\
\text { networking, } \\
\text { menamaba } \\
\text { h banyak } \\
\text { teman, dan } \\
\text { belajar } \\
\text { cara } \\
\text { berbisnis } \\
\text { yang baik }\end{array}$ & $\begin{array}{l}\text { Inovasi jasa } \\
\text { photograph } \\
\text { er dan } \\
\text { peningkata } \\
\text { n omset }\end{array}$ \\
\hline $\begin{array}{l}3 . \\
\text { Pengusaha } \\
\text { konstruksi }\end{array}$ & $\begin{array}{l}\text { Belajar } \\
\text { berorganisa } \\
\text { si dan } \\
\text { menambah } \\
\text { networking }\end{array}$ & $\begin{array}{l}\text { Mencari } \\
\text { pelung } \\
\text { bisnis baru }\end{array}$ \\
\hline $\begin{array}{l}4 . \\
\text { Pengelola } \\
\text { primagama } \\
\text { Gayung } \\
\text { Sari }\end{array}$ & $\begin{array}{l}\text { Menambah } \\
\text { networking, } \\
\text { mendapatk } \\
\text { an value, } \\
\text { dan } \\
\text { mendapatk } \\
\text { an rekan }\end{array}$ & $\begin{array}{l}\text { Menambah } \\
\text { inovasi agar } \\
\text { usaha } \\
\text { dapat } \\
\text { meningkat } \\
\text { lagi }\end{array}$ \\
\hline
\end{tabular}

\begin{tabular}{|c|c|c|}
\hline & bisnis & \\
\hline $\begin{array}{l}5 . \\
\text { Pengusaha } \\
\text { toko } \\
\text { klontong } \\
\text { dan jersey }\end{array}$ & $\begin{array}{l}\text { Menambah } \\
\text { networking } \\
\text { dan } \\
\text { menambah } \\
\text { pangsa } \\
\text { pasar }\end{array}$ & $\begin{array}{l}\text { Inovasi } \\
\text { penjualan } \\
\text { ready stock } \\
\text { jersey }\end{array}$ \\
\hline $\begin{array}{l}6 . \\
\text { Pengusaha } \\
\text { digital } \\
\text { printing }\end{array}$ & $\begin{array}{l}\text { Menambah } \\
\text { networking } \\
\text { dan } \\
\text { mendapatk } \\
\text { an informasi } \\
\text { tentang } \\
\text { dunia bisnis }\end{array}$ & $\begin{array}{l}\text { Pengemba } \\
\text { ngan usaha } \\
\text { digital } \\
\text { printing dan } \\
\text { pengelolaa } \\
\text { nSDM }\end{array}$ \\
\hline $\begin{array}{l}7 . \\
\text { Pengusaha } \\
\text { foto corner }\end{array}$ & $\begin{array}{l}\text { Menambah } \\
\text { networking }\end{array}$ & $\begin{array}{l}\text { Peningkata } \\
\mathrm{n} \text { omset } \\
\text { dan pangsa } \\
\text { pasar }\end{array}$ \\
\hline $\begin{array}{l}8 . \\
\text { Pengusaha } \\
\text { garmen } \\
\text { dan } \\
\text { marchenda } \\
\text { ise }\end{array}$ & $\begin{array}{l}\text { Menambah } \\
\text { networking, } \\
\text { mencari } \\
\text { rekan bisnis, } \\
\text { dan } \\
\text { menjaga } \\
\text { tali } \\
\text { silatuhrahmi }\end{array}$ & $\begin{array}{l}\text { Lebih } \\
\text { survive } \\
\text { dalam } \\
\text { menjalanka } \\
\mathrm{n} \quad \text { bisnis, } \\
\text { meningkatk } \\
\text { an } \\
\text { semangat } \\
\text { bekerja }\end{array}$ \\
\hline $\begin{array}{l}9 . \\
\text { Pengusaha } \\
\text { IT }\end{array}$ & $\begin{array}{l}\text { Menambah } \\
\text { link, } \\
\text { networking, } \\
\text { menjaga } \\
\text { hubungan } \\
\text { antar } \\
\text { sesama } \\
\text { pengusaha }\end{array}$ & $\begin{array}{l}\text { Meningkatk } \\
\text { an } \\
\text { perkemban } \\
\text { gan bisnis }\end{array}$ \\
\hline
\end{tabular}

Sumber : Data yang Sudah Dikelola 


\section{Bentuk Silaturahim Melalui Pergaulan Anggota HIPMI Surabaya}

Pergaualan memiliki pengertian yang sangat luas untuk dijabarkan dalam sebuah teori. Pergaualan merupakan bagian penting dalam kehidupan manusia mulai dari masyarakat kelompok kecil sampai dengan kelompok yang lebih luas. Pergaulan manusia itu sendiri terus berkembang seiring dengan kemajuan budaya, ilmu pengetahuan dan teknologi. Manusia memiliki kebutuhan untuk bergaul dengan orang lain dikarenakan pada hakekatnya manusia selalu butuh berinteraksi dengan manusia lain dalam kehidupannya. Pergaulan itu sendiri yang nantinya menciptakan silaturahim antara pengusaha yang satu dengan yang lainnya dan dapat mempengaruhi pengusaha dalam melakukan sesuatu, pergaulan yang salah akan mengakibatkan manusia melakukan hal yang bersifat negatif tetapi pergaulan yang baik akan menghasilan nilai positif. Kesuksesan manusia dalam bekerja atau berwirausaha juga sangat dipengaruhi oleh hubungan pertemanan yang pastinya berlandaskan kepercayaan.

Islam sendiri memiliki sebuah aturan tentang pergaulan, dimana pergavalan yang baik akan memberi manfaat yang besar bagi seseorang dan pergaulan yang tidak baik akan memberikan dampak yang tidak baik pula bagi seseorang. Nabi Muhammad SAW bersabda :

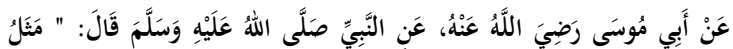

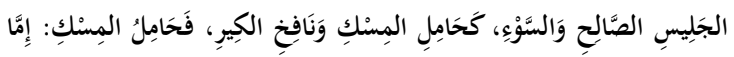

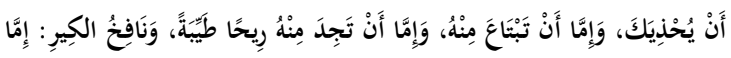

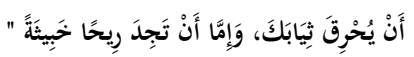

"Perumpamaan teman duduk yang baik dengan teman duduk yang jahat adalah seperti penjual minyak wangi dengan pandai besi. Adapun penjual minyak wangi tidak melewatkan kamu, baik engkau akan membelinya atau engkau tidak membelinya, engkau pasti akan mendapatkan baunya yang enak, sementara pandai besi ia akan membakar bujumu atau engkau akan mendapatkan baunya yang tidak enak." (HR. Bukhory dan Musilim).

Berdasarkan hadist tersebut dapat diambil faedah bahwasanya berteman dengan teman yang baik mempunyai 2 kemungkinan: (1) kita akan menjadi baik dan (2) kita akan memperoleh kebaikan yang dilakukan teman kita. Sebaliknya, memiliki teman yang jahat juga mempunyai 2 kemungkinan: (1) kita akan menjadi jelek dan (2) kita akan ikut memperoleh kejelekan yang dilakukan teman kita. Surat Al-Furqan: 27-29 :

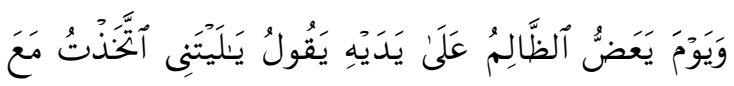
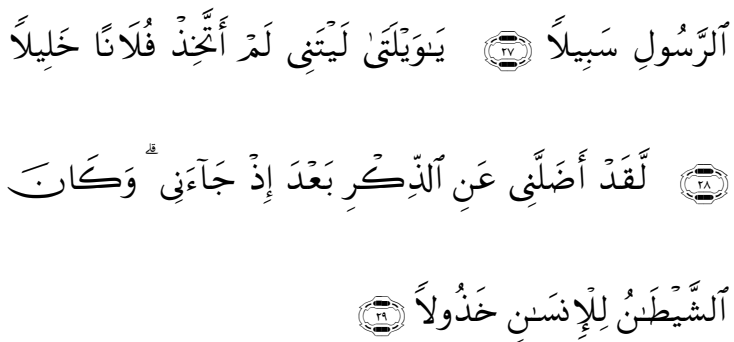

Wa yauma ya'adhdhuzh zhaalimu 'alaa yadaihi yaquulu yaa laitanit takhadztu 
ma'ar rasuuli sabiilaa. Yaa wailataa laitanii lam attakhidz fulaanan khaliilaa. La qad adhallanii 'anidz dzikri ba'da idz jaa-anii wa kaanasy syaithaanu lil insaani khadzuulaa.

"Dan ingatlah hari ketika orang-orang zhalim menggigit dua tangannya seraya berkata: Aduhai kiranya aku dulu mengambil jalan bersama-sama Rasul. Kecelakaan besar bagiku! Kiranya dulu aku tidak mengambil si fulan sebagai teman akrabku. Sesungguhnya dia telah menyesatkan aku dari Al-Quran sesudah Al-Quran itu datang kepadaku. Dan adalah syetan itu tidak mau menolong manusia."

\section{Dampak Silaturahim Pada Kinerja Usaha Anggota HIPMI Surabaya}

Pengusaha anggota HIPMI Surabaya yang memiliki kegiatan baik formal di dalam himpunan organisasi maupun di luar telah menciptakan hubungan interaksi sosial atau merupakan komunikasi interpersonal. Hubungan tersebut berdampak kepada kinerja pengusaha anggota HIPMI Surabaya, yang bisa dilihat dari perubahan indikator di bawah ini.

\section{E. Value}

Value atau nilai dapat digambarkan oleh pengusahapengusaha HIPMI Surabaya tentang mengelola bisnis, networking, dan lain-lain yang dapat mempengaruhi pengusaha atau usaha yang sedang dikelola. Beberapa pengusaha yang telah diwawancarai dalam penelitian ini menjelaskan bahwa dari semua kegiatan yang berhubungan dari HIPMI Surabaya mendatangkan value, khususnya ketika berinteraksi bersama teman-teman pengusaha yang lain.

\section{Omset}

Omset adalah ukuran nominal untuk mengetahui bagaimana suatu perusahaan berhasil menjalankan bisnisnya. Salah satu ukuran dalam penelitian ini adalah bagaimana kinerja dari usaha atau bisnis yang dijalankan pengusaha HIPMI Surabaya. Pergaulan yang ada di dalam lingkungan HIPMI Surabaya telah memberikan dampak dalam bentuk bermacam-macam bagi pengusaha yang telah diwawancarai di penelitian ini. Dampak tersebut oleh penulis dapat dilihat dari hasil wawancara mengenai kinerja masing-masing dari usaha yang telah dikelola.

\section{F. Laba}

Laba adalah jumlah pendapatan setelah dikurangi dengan beban-beban yang lain. Dampak dari pergaulan di HIPMI Surabaya kepada laba ini mengikuti omset yang dihasilkan oleh ke tujuh pengusaha yang telah diwawancarai dalam penelitian ini. Laba yang berhasil pengusaha dapatkan tergantung dari juamlah omset dan pertumbuhan dalam setiap bulannya. Peneliti memiliki keterbatas untuk mengetahui secara detail tentang data nominal dari usahausaha yang dimiliki para pengusaha. Hal ini disebabkan karena dari keseluruhan, ada pengusaha yang menolak untuk menunjukkan data nominal tersebut dan 
ada juga yang data laporan keuanganya belum tertata. Pengusaha hanya memberikan penjelasan secara lisan mengenahi perkembangan omset atau laba dari usaha yang dihasilkan melalui wawancara dan estimasi pengusaha sendiri.

\section{G. Pangsa Pasar}

Secara otomatis, dengan meningkatnya omset, laba, dan value, pangsa pasar dari usaha masing-masing pengusaha mengalami perubahan. Seperti pengusaha barang antik, meskipun tidak mengalami peningkatan omset yang signitifikan akan tetapi terbantu oleh saran-saran dari pengusaha lain dalam merangkul konsumen lebih luas lagi. Pada mulanya pengusaha sangat kesulitan dalam mengembangkan usahanya, hanya saja dengan kesabaranya dan sharing bersama anggota HIPMI yang lainya akhirnya mendapatkan cara untuk menambah konsumen lebih banyak lagi.

\section{H. Tenaga Kerja}

Usaha yang telah diciptakan oleh pengusaha-pengusaha muda HIPMI Surabaya selain membantu perekonomian di surabaya juga membantu dalam penyerapan tenaga kerja di sector UKM. Sembilan jenis usaha yang berbeda dari setiap pengusaha memberikan lapangan pekerjaan yang baru di Surabaya.

\section{Pembahasan Terintegritas}

Kegiatan-kegiatan HIPMI Surabaya melalui agenda rutin formal ataupun agenda non-formal memberikan stimulus bagi pengusaha-pengusaha yang tergabung di dalam keanggota HIPMI Surabaya. Kegiatan-kegiatan tersebut memberikan waktu yang lebih kepada pengusaha-pengusaha tersebut untuk berinteraksi sosial melalui pergaulan sesama pengusaha. Interaksi sosial yang terjalin atau komunikasi interpersoanal antara pengusaha di dalam Islam di sebut dengan silaturahim, hal ini dilandasi dari bebrapa kajian teori tentang pengertian silaturahim yang tidak hanya sebagai hubungan saudara, akan tetapi silaturahim memiliki manfaat sebagai pembuka pintu rezeki seperti yang terkandung di dalam hadist Rasullulalah SAW. Sinergi antara pengusaha yang satu dengan yang lainnya memberikan bentuk kerja sama yang saling menguntungkan serta dengan bersilaturahim para pengusaha mendapatkan dampak pada kinerja usaha dari bisnis-bisnis yang dikelola masing-masing. Pengukuran kinerja di dalam penelitian ini berdasarkan pada teori pengukuran kinerja BSC yang dikembangkan oleh Kaplan dan Norton pada tahun 1996. Pengukuran tersebut dengan melihat prespektif keuangan, prespektif pelanggan, prespektif proses internal, dan prespektif pertumbuhan dan pemebelajaran. Maka penelitian ini secara keseluruhan mengukur kinerja pengusaha HIPMI Surabaya dengan indikator value sebagai nilai-nilai yang didapatkan dari silaturahim antara pengusaha yang satu dengan yang lainnya, Omset dan laba sebagai nilai nominal dari pengukuran antara periode 
yang satu dengan periode yang lain, pangsa pasar sebagai pengukuran bagaimana perusahaan dapat meraih atau mempertahankan konsumen, dan tenaga kerja sebagai pengukuran bagaimana suatu usaha dapat menciptakan lapangan pekerjaan yang baru.

Melalui hasil wawancara kepada para pengusaha, bahwa silaturahim dalam pergaulan memberikan dampak pada kinerja usaha anggota HIPMI Surabaya. Penilaian para pengusaha dalam mengukur kinerja masing-masing bisnis yang dikelolanya hanya berdasarkan pada pendekatan subjektif, yaitu hanya melalui persepsi pelaku usaha. Hal ini dikarenakan para pengusaha tidak memiliki data nominal yang akurat dalam usaha yang dikelola.

\section{KESIMPULAN DAN SARAN}

\section{A. Simpulan}

Berdasarkan hasil analisis dan pembahasan, pengusaha telah menciptakan hubungan interaksi sosial atau merupakan komunikasi interpersonal yang timbul di dalam pergaulan organisasi HIPMI Surabaya. Bentuk implementasi pergaulan itu sendiri adalah kegiatan-kegiatan non formal yang dilakukan oleh beberapa kelompok kecil misalnya berolah raga bersama, menghabiskan waktu bersama diluar atau sekedar sharing di tempat-tempat tertentu. Kegiatan tersebut yang pada akhirnya menimbulkan komunikasi interpersonal antar sesama anggota. Pergaulan tersebut mengakibatkan kebersamaan dalam waktu yang sering dan memberikan pembahasan tentang dunia bisnis yang berdampak meningkatnya kerja keras para pengusaha.

Kerja keras tersebut menghasilkan kinerja bagi anggota HIPMI Surabaya dan peningkatan income, berkembangnya usaha, dan bertambahnya value. Menurut pengusaha yang menjadi anggota HIPMI Surabaya dengan mengikuti kegiatan dan aktif dalam organisasi, akan menambah networking, dan bertambahnya omset dari bisnisnya.

\section{B. Saran}

Saran yang dapat penulis sampaikan dalam penelitian ini adalah :

1. Bagi pemerintah, semakin banyak wirausahawan, lapangan kerja akan terbuka sehingga HIPMI dapat membantu menekan angka pengangguran. maka, dengan kinerja pengusaha HIPMI Surabaya yang semakin baik dapat membantu perekonomian baik di Surabaya ataupun di Indonesia

2. Bagi HIPMI Surabaya, untuk bisa memberikan kontribusi berkelanjutan bagi para anggota dan pengusaha muda di Surabaya melalui kegiatankegiatan yang dapat memberikan sinergi antara pengusaha yang satu dengan yang lainnya.

3. Penelitian ini bisa bermanfaat bagi pengembangan ilmu.

4. Bagi penelitian selanjutnya, agar dilakukan penelitian yang lebih mendalam mengenai seberapa besar 
dampak pengusaha-pengusaha HIPMI Surabaya terhadap perekonomian kota Surabaya.

\section{DAFTAR PUSTAKA}

2011. Kewirausahaan. Bandung: Alfabeta.

Alma, Buchari. 2009. Studi Kasus Desain \& Metode. Jakarta: PT. Raja Grafindo Persada.

Al-Qur'an dan Terjemahanya. 2005. Tim Disbintalad. Jakarta: Sari Agung.

Arwani, Ahmad. 2010. 8 Kunci Sukses Berbinis Rasulullah SAW. Jakarta: Inti Medina.

As'ad, Moh. 1987. Psikologi Industri Edisi Ketiga Cetakan Pertama. Yogyakarta : Liberty.

Bahreisy, Hussein. 2001. Hadist Shahih Bukhari: Himpunan Hadist Pilihani. Surabaya: Al-Ikhlas

Basrowi. 2011. Kewirausahaan untuk Perguruan Tinggi. Cetakan Pertama. Bogor: Penerbit Ghalia Indonesia.

Bungin, B. 2003. Analisis Data Penelitian Kualitatif. Jakarta: PT Rajagrafindo.

Dessler, Gary. 2007. Manajemen Sumber Daya Manusia. Edisi 10. Jakarta: PT. Indeks.

Donaldson, Lex, 2001, The Contingency Theory of Organizations, New Delhi, India Sage Publication, Inc

Fadhlur, Ridhan R. 2013. Pengaruh Etos Kerja Islam Terhadap Kinerja Islam Karyawan dengan Variabel Moderator Motivasi Kerja Pada Bank Muamalat. Skripsi tidak diterbitkan. Surabaya Ekonomi dan Bisnis Universitas Airlangga.

Fiesto. 2012. HIPMI, Inkubator Bisnis Pengusaha Muda Surabaya, (Online), (http://iklanpos.co.id/?p=4765, diakses 18 Juni 2013).

Freser, TM. 1992. Stres Kerja dan Kepuasan Kerja. Jakarta: PT. Pustaka Binamen Pressindo.

Furtwengler, Dale. (2002).Penilaian Kinerja. Yogyakarta: ANDI.

Gomes, Faustino Cardoso, 2000. Manajemen Sumber Daya Manusia. Cetakan Keempat. Yogyakarta: Penerbit Andi.

Gray, Jerry L., Frederic A. Starke, organization Behavior, Concepts, and Applications, Charles E., Merrill Publ. Company, Columbus, 1984.

Hafidhuddin, Didin dan Hendri Tanjung. 2003. Manajemen Syariah dalam Praktek. Jakarta: Gema Insani.

Handoyo, Agus. 2001. Pengaruh Orientasi Wirausaha Terhadap Kinerja Perusahaan Kecil dengan Lingkungan dan Strategi sebagai Variabel Moderat". Tesis tidak diterbitkan. Semarang Pascasarjana Universitas Diponegoro.

Hansen, Don R. Maryanne Moven. 2005. Management Accounting. Edisi 7 , Jakarta: Penerti salemba

Hasibuan, Malayu S.P. 2003. Organisasi dan Motivasi. Jakarta : Bumi Aksara. 
Kaplan, Robert S and David P Norton, 2006, Aligement: Using Balanced Scorecard to Create Corporate Sinergies, Boston, Harvard Bussines School Publishing Corporation

Kartajaya, Hermawan dan Syakir S. 2006. Syariah Marketing. Bandung:Mizan Media Utama.

Khoirunnisa, Labbaika. 2013. Dampak Ketaqwaan Pada Kesuksesan (Studi Kasus: Pengusaha Fesyen di Surabaya). Skripsi tidak diterbitkan. Surabaya Ekonomi dan Bisnis Universitas Airlangga.

Mangkunegara. Anwar Prabu, 2005. Evaluasi Kinerja Sumber Daya Manusia. PT Refika Aditama, Cetakan Pertama, Bandung.

Mangkuprawira, Tb. Sjafri, 2009. Bisnis, Manajemen, dan Sumberdaya Manusia. Bogor : IPB Press.

Moleong, Lexy. 2005. Metode Penelitian Kualitatif. Bandung: PT Remaja

Nawawi, Imam. 1999. Terjemah RIYADHUS SHALIHIN. Jakarta: Pustaka Amani.

Persada.

Prawirosentono. Suyadi (1999). Kebijakan Kinerja Karyawan. Edisi Pertama, BPFE. Yogyakarta. Publishing House.

Rich, Ustad dan Laode.20ll. Rasulullah's Business School, Jakarta: Ihwah.

Rivai, Veithzal. 2012. Islamic Marketing. Jakarta: PT Gramedia Pustaka Utama.

Rosdakarya.
Sirait, Justin T. 2006. Memahami aspekaspek pengelolaan Sumber Daya Manusia Dalam Organisasi. Jakarta: Grasindo.

Snell, SA., 1992. Diagnosa Kinerja: Mengenali Penyebab Kinerja Buruh. Dalam A. Dale Temple (ED). Seri Ilmu dan Manajemen Bisnis Kinerja. Jakarta: Alih Bahasa Cikmat, Elex MK.

Stoner, James A.F \& Edward Freeman. 1996. Manajemen jilid I. Alih bahasa Alexander Sindoro. PT. Prenhallindo, Jakarta.

Suci, Rahayu Puji. 2009. Peningkatan Kinerja Melalui Orientasi Kewirausahaan, kemampuan Manajemen, dan Strategi Bisnis (Studi pada Industri Kecil Menengah Bordir di Jawa Timur). Jurnal Manajemen Dan Kewirausahaan, 11 (1): 48-49.

Sugiyono. 2007 . Metodologi Penelitian Pendidikan. Bandung: Alfabeta.

Supranto, J. (2001), Pengukuran Tingkat Kepuasan pelanggan Untuk Menaikkan Pangsa Pasar Rineke Cipta. Jakarta.

Suranto, 2011. Komunikasi Interpersonal. Yogyakarta: Graha llmu.

Syafi'i Antonio, Muhammad.2007. Muhammad Saw the super leader super manager. Jakarta : Tazkia Multimedia dan Prophetic Leadership \& Management.

Taman, Agus. 2008. Model Pengukuran Kinerja Perusahaan dengan Metode SMART SYSTEM (Studi 
Kasus pada UKM CV. BATARA

ELEKTRINDO), (Online),

(http://gunadarma.ac.id/library/

articles/graduate/economy/2009

|Artikel_10205056.pdf, diakses 20 Januari 2014).

Wibowo, 2008. Manajemen Kinerja. Jakarta : PT Raja Grafindo Persada.

Winardi, J, 2007. Motivasi dan pemotivasian dalam manajemen. Jakarta : PT Raja Grafindo Persada.

Yin, Robert. 2002. Studi Kasus Desain dan Metode. Jakarta: PT Raja Grafndo Persada.

Zadjuli, (1999). Membentuk Manusia menjadi Khalifah di Bumi yang Makdaniyah. Pusat Studi Kebijakan Alternatif: Surabaya 